\title{
Assessment of body composition and breast milk volume in lactating mothers in pastoral communities in Pokot, Kenya, using deuterium oxide
}

Citation for published version (APA):

Ettyang, G. A., van Marken Lichtenbelt, W. D., Esamai, F., Saris, W. H., \& Westerterp, K. R. (2005). Assessment of body composition and breast milk volume in lactating mothers in pastoral communities in Pokot, Kenya, using deuterium oxide. Annals of Nutrition and Metabolism, 49(2), 110-117. https://doi.org/10.1159/000084744

Document status and date:

Published: 01/01/2005

DOI:

10.1159/000084744

Document Version:

Publisher's PDF, also known as Version of record

Please check the document version of this publication:

- A submitted manuscript is the version of the article upon submission and before peer-review. There can be important differences between the submitted version and the official published version of record.

People interested in the research are advised to contact the author for the final version of the publication, or visit the DOI to the publisher's website.

- The final author version and the galley proof are versions of the publication after peer review.

- The final published version features the final layout of the paper including the volume, issue and page numbers.

Link to publication

\footnotetext{
General rights rights.

- You may freely distribute the URL identifying the publication in the public portal. please follow below link for the End User Agreement:

www.umlib.nl/taverne-license

Take down policy

If you believe that this document breaches copyright please contact us at:

repository@maastrichtuniversity.nl

providing details and we will investigate your claim.
}

Copyright and moral rights for the publications made accessible in the public portal are retained by the authors and/or other copyright owners and it is a condition of accessing publications that users recognise and abide by the legal requirements associated with these

- Users may download and print one copy of any publication from the public portal for the purpose of private study or research.

- You may not further distribute the material or use it for any profit-making activity or commercial gain

If the publication is distributed under the terms of Article 25fa of the Dutch Copyright Act, indicated by the "Taverne" license above, 


\title{
Assessment of Body Composition and Breast Milk Volume in Lactating Mothers in Pastoral Communities in Pokot, Kenya, Using Deuterium Oxide
}

\author{
G.A. Ettyang ${ }^{a}$ W.D. van Marken Lichtenbelt ${ }^{c}$ F. Esamai ${ }^{\mathrm{b}}$ W.H.M. Saris ${ }^{\mathrm{c}}$ \\ K.R. Westerterp ${ }^{c}$ \\ Departments of ${ }^{a}$ Human Nutrition and Dietetics, and ${ }^{b}$ Child Health, FHS, Moi University, Eldoret, Kenya, \\ and ${ }^{\mathrm{C}}$ Department of Human Biology, Maastricht University, Maastricht, The Netherlands
}

\section{Key Words}

Lactation · Isotope dilution · Breast milk intake · Body composition · Fat-free mass $\cdot$ Body fat $\cdot$ Total body water

\begin{abstract}
Background: In sub-Saharan Africa, the practice of breast-feeding infants is common. Records documenting the intake of breast milk amongst infants are limited. This study evaluated the association between maternal body composition and the intake of breast milk in infants from the pastoral communities within Pokot, Kenya. Methods: The study was conducted in 10 lactating mothers who were participating in a longitudinal study aimed at determining maternal body composition, iron stores and vitamin A status during the third trimester pregnancy and four months after they had given birth. Maternal and infant anthropometric measurements were made, and maternal blood samples were taken to determine serum retinol and ferritin levels. Infant milk intake and maternal fat-free mass (FFM) and percent body fat (\% BF) were measured using 'the dose to the mother method'. A measured deuterium oxide $\left({ }^{2} \mathrm{H}_{2} \mathrm{O}\right)$ dose was given to the mother. Urine and breast milk from the mother, and saliva samples from the infant, were collected on days
\end{abstract}

1, 8 and 14 after dosing. Results: The mean ( \pm SD) maternal mid upper arm circumference (MUAC) and body mass index (BMI) were $21.8(0.9) \mathrm{cm}$ and $18.6(1.0) \mathrm{kg} /$ height $\left(\mathrm{m}^{2}\right)$, respectively. Infant weight and weight/age Z score were 4.956 (0.874) kg and -1.750 (0.77), respectively. Throughout the study, the infants gained 20 (4) g/day in body weight and had a milk intake of 555 (22) $\mathrm{ml} /$ day. The energy intake of the infant was 1,602 (148) $\mathrm{kJ} /$ day and was lower $(\mathrm{p}<0.05$ ) than the 2,404 (423) $\mathrm{kJ} /$ day estimated requirement by the $\mathrm{FAO}$ WHO/ UNU. The maternal FFM, \%BF, Hb, Hct, ferritin and retinol were $32.8(3.1) \mathrm{kg}, 17.24$ (7.0), 11.5 (1.3) g/dl, 33.9 (4.9), $16.2(0.1) \mu \mathrm{g} / \mathrm{l}$ and 0.894 (0.16) $\mu \mathrm{mol} / \mathrm{l}$, respectively. Infant milk intake was significantly and positively correlated to maternal pregnancy triceps $(r=0.679) p<0.05)$ and pregnancy MUAC ( $r=0.725) \mathrm{p}<0.05)$. Maternal pregnancy MUAC was an important predictor of infant breast milk intake. Conclusion: Data on volume of breast milk consumed by the infants suggests, at least for this group of infants, that adequate growth may not be achieved. There is a possibility that lactating mothers practicing exclusive breast-feeding and living under harsh conditions may experience periods of low breast milk volume. Body composition and biochemical findings among this group of Pokot mothers indicate dietary inadequacies that require nutritional intervention.

Copyright (C) 2005 S. Karger AG, Basel
Ms. Grace Adisa Ettyang

Department of Human Nutrition and Dietetics, Faculty of Health Sciences

Moi University, PO Box 4606

Eldoret (Kenya)

Tel. +254 0722 609257, Fax +2540321 33041, E-Mail gaettyang@yahoo.com

\begin{tabular}{llll}
\hline KARGER & ( ) 2005 S. Karger AG, Basel & Ms. Grace Adisa Ettyang \\
Fax +4161306 1234 & 0250-6807/05/0492-0110\$22.00/0 & Department of Human Nutrition and Dietetics, Faculty of Health Sciences \\
$\begin{array}{l}\text { E-Mail karger@karger.ch } \\
\text { www.karger.com }\end{array}$ & $\begin{array}{l}\text { Accessible online at: } \\
\text { www.karger.com/anm }\end{array}$ & Moi University, PO Box 4606 \\
Eldoret (Kenya) \\
Tel. +254 0722 609257, Fax+254 0321 33041, E-Mail gaettyang@yahoo.com
\end{tabular}




\section{Introduction}

In countries of sub-Saharan Africa, the practice of breast-feeding infants is common. Records documenting the intake of breast milk amongst infants are limited even though breast milk plays an important role in meeting the energy requirements for infant growth [1,2]. Current guidelines for these countries recommend exclusive breastfeeding until the child is at least 6 months old [3]. Particularly evident is the inadequacy of crucial data evaluating the nutritional adequacy of exclusive breast-feeding during the first 4-6 months of infant life. The accuracy, cheapness and ready availability of deuterium oxide (DO) $\left({ }^{2} \mathrm{H}_{2} \mathrm{O}\right)$ has led to its extensive use in measuring body composition [4] and in the estimation of infant breast milk intake $[5,6]$. The method offers an opportunity to determine maternal body composition and breast milk output at the same time. Studies that have used the DO dilution method to investigate the milk intake of breast-fed infants from developing countries are very few $[7,8]$. In sub-Saharan Africa, only one body composition validation study in 10 lactating women living in Nandi, a rural community in Kenya, has been done by Ettyang et al. [9].

Lack of data from developing countries seriously hinders the evaluation of the nutritional adequacy of human milk intake amongst exclusively breast-fed infants. Evidence to date clearly indicates that few women exclusively breast-feed beyond 4 months [10]. Environmental factors adversely affect the maternal food intake thus putting them at risk for underweight as well as reducing the volume of breast milk they may produce. Numerous socioeconomic and cultural factors influence their decision to supplement human milk. In developing countries, maternal work demands are among the factors that determine the need and timing of complementary feeding.

The present study was conducted in West Pokot, a part of Kenya where environmental and life style factors have adversely affected maternal and child nutritional status [11]. Undernutrition amongst the worst affected pastoral and farming households is a function of declining food availability and is exacerbated by chronic food insecurity. In view of poor rains, conflict and other hazards, the security of food is increasingly fragile. Therefore, the aim of this study was to evaluate the association between the intake of breast milk of pastoral infants who were exclusively breast-fed and the body composition of their mother; body composition was measured using the isototopic method. In addition, the relationship between the energy cost of growth and energy density of the breast milk was examined.

\section{Materials and Methods}

\section{Study Community}

The study was conducted in the West Pokot district of Kenya. The women, all from the pastoral community living in the Chepkobeh location, were participants in a longitudinal study aimed at determining the prevalence of undernutrition, low iron stores and vitamin A deficiency during the third trimester pregnancy and at 4 months after birth. Maternal body composition and breast milk intake of the infants were measured in 10 lactating women. The selection criteria included: exclusive breast-feeding, having an infant aged 2-4 months, maternal parity $\leq 4$, birth weight of more than $2,500 \mathrm{~g}$, and no congenital abnormalities. From all women in the longitudinal population who met these criteria, 10 were randomly selected for this study. Approval for the research was obtained from both the Moi ethical and research committee and the government of Kenya. The objectives and procedures of the study were explained to the women. Only women who gave informed consent were studied. Given the logistic requirements and the difficult terrain, the 10 mothers and infants that were selected were invited to sleep one night at the home of one of the villages' traditional birth attendants. Procedures for the collection of samples were explained and mothers asked to return to the same home on days 8 and 14 .

\section{The DO Dilution Method}

The volume of breast milk consumed can be estimated from measurements of the rate of water turnover after the oral administration of a measured DO dose to either the mother or the infant. Estimation of the infant breast milk intake by the 'dose-to-themother' method has been described by Coward et al. [5] and validated in 10 infants from a nutritional recovery center in Santiago, Chile, by Infante et al. [12]. One advantage of the DO technique is that the measurement of body composition can also be made. Use of the method avoids inclusion of infant water intake from other sources in the calculation of breast milk intake. It also eliminates the need to time milk sample collection and allows for breast milk intake to be studied without interfering with the normal feeding pattern of the child. In this study, DO was used as a tracer to follow the movement of water (trace) into and out of the body water pools of the mother and her breast-fed infant [5]. By giving DO to the mothers, we were able to measure the volume of milk consumption in their breast-fed infants. The basic measurement obtained was a value that is related to the effects of all feeds consumed by the infant over a period of 14 days; therefore, the results are comparable to other isotope dilution studies done in other parts of the world.

\section{Collection of Urine Samples}

The stock mixture of DO was prepared from separate(un)labeled water accordingly to the Maastricht protocol [4]. A background urine sample was collected in the evening, 5-10 min before the DO intake. The mothers were given a standard dose of $70 \mathrm{ml}$ of water with 5 APE deuterium [13]. The next morning, 1-3 h before the final urine sampling, the mothers were asked to completely empty their bladder; this urine was not collected. A second urine specimen was collected $1 \mathrm{~h}$ later for analysis. As much as possible, the time between drinking the deuterium and the last urine sampling was $10 \mathrm{~h}( \pm 10 \mathrm{~min})$. The urine samples were frozen and stored at $-70^{\circ}$ $\mathrm{C}$ until transported to the analytic laboratory in Maastricht. 


\section{Breast Milk and Saliva Samples}

A $100-\mu 1$ sample of expressed breast milk from the mother and a saliva sample from her infant were collected at the time of urine sample collection (day 0 ). She was given an accurately weighed dose of DO. At least three further milk and saliva samples were collected to provide estimates of DO enrichment at days 1,8 and 14 Sample collection on day 0 was done to ensure that the dose of DO reached equilibrium overnight within the mother [4]. The samples were frozen in glass-topped vials at $-70^{\circ} \mathrm{C}$ and transported to the analytic laboratory in Maastricht.

\section{Anthropometry and Blood Collection}

The mother's body weight was measured to the nearest $0.1 \mathrm{~kg}$ using an electronic scale (SECA). Height was measured to the nearest $0.1 \mathrm{~cm}$ using a stadiometer. Body mass index $\left(\mathrm{BMI} \mathrm{kg} / \mathrm{m}^{2}\right)$ was computed from weight in $\mathrm{kg} /$ (height $\times$ height in meters). Biceps, triceps, suprailiac and subscapular skinfold thickness were measured using a Holtain skinfold thickness caliper (UK); all measurements were done in triplicate by the same investigator [14]. The infant's body weight was measured to the nearest $0.1 \mathrm{~kg}$ with a baby weighing scale and height was measured to the nearest 0.1 $\mathrm{cm}$ with a height stadiometer. Infants were weighed again at the end of the 14-day period. 5-ml venous blood samples taken from the mother were stored on ice for transportation to the laboratory. On arrival, serum was separated from blood by centrifugation at room temperature, and at 3,000 rpm for $15 \mathrm{~min}$. Thereafter, the serum samples were stored at $-70^{\circ} \mathrm{C}$ until analyzed for retinol and ferritin.

\section{Biochemical Analysis}

A Coulter counter (model 560) was used to determine hemoglobin $(\mathrm{Hb})$ and hematocrit ratio (Hct). Retinol levels in serum were assayed using high-performance liquid chromatography (HPLC). Measurements of serum ferritin (SF) were performed using the enzyme-linked immunosorbent assay (ELISA Boehringer Mannheim Immundiagnostike Mannheim, Germany). Nutritional anemia was assessed using both $\mathrm{Hb}$ and $\mathrm{Hct}$ [15]. The lactating mothers were categorized as having anemia if their $\mathrm{Hb}$ levels were $<12 \mathrm{~g} / \mathrm{dl}$ or their Hct ratio was $<37$. Depletion of iron stores was based on the levels of SF concentration: $<12 \mu \mathrm{g} / 1$ indicates severe depletion, $12-$ $29 \mu \mathrm{g} / \mathrm{l}$ marginal depletion and $\geq 30 \mu \mathrm{g} / \mathrm{l}$ indicates normal stores. Vitamin A status was based on serum retinol concentration: $<0.35 \mu \mathrm{mol} / \mathrm{l}(10 \mu \mathrm{g} / \mathrm{dl})$ indicates vitamin A deficiency and $<0.70 \mu \mathrm{mol} / 1(20 \mu \mathrm{g} / \mathrm{dl})$ reflects marginal deficiency.

\section{Determination of Body Composition, Breast Milk Volume and} Infant Energy Intake

After preparation with the Pt equilibration technique [16], the urine samples were analyzed with an isotopic ratio mass spectrometry (Aqua Sira VG UK, Cheshire). Deuterium was measured in hydrogen gas. Hydrogen gas was produced from the sample online by the hot uranium technique. The ${ }^{2} \mathrm{H}$ enrichment in 5-7 $\mu$ l of milk and saliva water samples was measured by reductions of the water to hydrogen gas and subsequent ${ }^{2} \mathrm{H}$ analysis using an isotopic ratio mass spectrometry [17]

The fat-free mass (FFM) was calculated as TBW/0.724 as suggested by Raaij et al. [18]. Maternal body fat (BF) and \%BF was calculated from body weight $(\mathrm{BW})$ by difference. Thus, $\mathrm{BF}=$ $\mathrm{BW}-\mathrm{FFM}$ and $\% \mathrm{BF}=(\mathrm{BF} \times 100) / \mathrm{BW}[13]$. Milk volume was assessed assuming a proportion of $96 \%$ of water after complete reduc-
Table 1. General and biochemical data of the 10 Pokot mothers measured during pregnancy and lactation

\begin{tabular}{lcc}
\hline & $\begin{array}{l}\text { Pregnancy } \\
\text { (3rd trimester) }\end{array}$ & $\begin{array}{l}\text { Lactation } \\
\text { (at 2-4 months) }\end{array}$ \\
\hline Parity & 3 & 4 \\
Weight, kg & $51.9 \pm 3.1$ & $49.5 \pm 0.8$ \\
BMI & $19.8 \pm 1.3$ & $18.6 \pm 2.7$ \\
MUAC & $22.7 \pm 1.2$ & $21.8 \pm 0.9$ \\
Hb, g/dl & $9.9 \pm 2.5$ & $11.5 \pm 1.3^{* *}$ \\
Hct & $32.0 \pm 4.5$ & $33.9 \pm 4.9$ \\
Ferritin, $\mu \mathrm{g} / 1$ & $23.4 \pm 0.1$ & $16.2 \pm 0.1^{*}$ \\
Retinol, $\mu \mathrm{mol} / 1$ & $0.735 \pm 0.290$ & $0.894 \pm 0.160^{*}$ \\
\end{tabular}

Values are mean \pm SD.

$* \mathrm{p}<0.05$ based on paired t test, ${ }^{* *} \mathrm{p}<0.01$ based on paired $\mathrm{t}$ test.

BMI = Body mass index (weight $\mathrm{kg} /$ height $\left(\mathrm{m}^{2}\right) ; \mathrm{MUAC}=\mathrm{mid}$ upper arm circumference.

tion of its solids [5]. Estimation of gross energy intake from the breast milk was based on $2.9 \mathrm{~kJ} / \mathrm{g}(0.67 \mathrm{kcal} / \mathrm{g})$ [19].

\section{Statistical Analyses}

Data were analyzed with the SPSS/PC statistical package (Version 9.2, 1998). Means, SDs and median were calculated for all outcome measurements. Independent samples Student's t test was used to determine the significance of the differences between means. The $\chi^{2}$ was used to compare the difference between proportions. Pearson's correlation tests were performed to examine the relationships between body composition, breast milk volume, serum retinol and measures of iron status. Multiple regression was used to identify determinants of infant breast milk intake. The predictor variables used were: skinfold thickness measurements, MUAC, BMI, FFM, BF, serum retinol, serum ferritin. Using $\mathrm{p}>$ 0.10 for exclusion, the significant $(p<0.01)$ combination of variables related to volume of infant breast milk intake were identified.

\section{Results}

General and biochemical data for the mothers measured during the 3rd trimester of pregnancy as well as during the lactation period (2-4 months after birth) are reported as mean $( \pm \mathrm{SD})$ and shown in table 1. Although not significant, body weight during pregnancy was reduced from 51.9 (3.1) $\mathrm{kg}$ to 49.5 (2.7) $\mathrm{kg}$ during lactation. There were significant $(\mathrm{p}<0.05)$ reductions in BMI from 19.8 (1.3) to 18.5 (1.0). Hb increased significantly ( $\mathrm{p}<$ $0.05)$ from $9.9(2.5) \mathrm{g} / \mathrm{dl}$ to $11.5(1.3) \mathrm{g} / \mathrm{dl}$. The level of serum ferritin was significantly $(\mathrm{p}<0.05)$ reduced from $23.4(0.1) \mu \mathrm{g} / \mathrm{l}$ during pregnancy to $16.2(0.1) \mu \mathrm{g} / \mathrm{l}$ during 
lactation. Serum retinol levels significantly $(p<0.05)$ increased during lactation as compared to during pregnancy $[0.894(0.16)$ vs. $0.736(0.29) \mu \mathrm{mol} / 1$, respectively]. Pregnancy levels of Hct were significantly correlated with infant milk intake per day $(r=0.699, p<0.05)$ and with

Table 2. Body composition of lactating Pokot and Nandi mothers

\begin{tabular}{lcc}
\hline & Pokot study & Nandi study $^{\mathrm{a}}$ \\
\hline Total body water & $24.0 \pm 2.3$ & $31.8 \pm 3.4$ \\
Total body water \% & $48.5 \pm 4.1$ & $52.0 \pm 7.8$ \\
Fat free mass, kg & $32.8 \pm 3.1$ & $44 \pm 4.7^{* *}$ \\
Body fat, kg & $8.7 \pm 3.8$ & $16.7 \pm 8.8$ \\
\% Body fat & $17.3 \pm 7.0$ & $26.2 \pm 8.1^{* *}$ \\
BMI & $18.5 \pm 1.0$ & $23.4 \pm 4.0^{* *}$ \\
MUAC & $22.7 \pm 1.16$ & $23.4 \pm 4.0^{* *}$ \\
Average skinfold thickness, $\mathrm{mm}$ & & \\
$\quad$ Biceps & $5.3 \pm 1.16$ & $9.9 \pm 6.7^{*}$ \\
$\quad$ Triceps & $14.7 \pm 3.4$ & $16.7 \pm 6.7$ \\
\hline
\end{tabular}

Values are mean $\pm \mathrm{SD}$.

${ }^{a}$ Same deuterium dilution technique used [4, 10].

${ }^{\mathrm{b}}$ Expressed as a percentage of body weight.

$\mathrm{BMI}=$ Body mass index $\left(\right.$ weight $\mathrm{kg} /$ height $\left.\mathrm{m}^{2}\right) ; \mathrm{MUAC}=\mathrm{mid}$ upper arm circumference.

$* \mathrm{p}<0.05$ based on independent samples t test.

$* * \mathrm{p}<0.01$ based on independent samples t test. lactation $\mathrm{Hb}(\mathrm{r}=0.639, \mathrm{p}<0.05)$. Pregnancy levels of retinol were significantly correlated with $\mathrm{FFM}(\mathrm{r}=-0.919$, $\mathrm{p}<0.05)$ and with $\%$ body fat $(\mathrm{r}=0.767, \mathrm{p}<0.05)$ during lactation.

As shown in table $2, \%$ body water of the Pokot mothers is lower than that of the lactating mothers in the Nandi study [48.5 (4.1) vs. $52.0(7.8) \%$, respectively] [10]. The Pokot mothers' \% body fat of $17.3(7.0)$ is lower compared to 26.4 (6.4) for the Nandi mothers. The Pokot mothers BMI of 18.5 (1.0) may be indicative of a prolonged low energy intake.

Data on water turnover rates in Pokot mothers compared to values reported by Coward et al. [4] for lactating mothers from Gambia and Papua New Guinea are shown in table 3. During the study period, Pokot women had a relatively low mean (SD) total body water $\%$ of 48.5 (4.1) compared to the value of 59.7 (2.7) and 50.9 (1.9) for the women in Gambia and Papua New Guinea, respectively. The 4.77 (0.95) liters/day water turnover observed in Pokot lactating mothers was lower than that reported for the women in Gambia [5.93 (0.25) liters/day]. The estimated intake of breast milk by the Pokot infants [552 (22) ml/ day] was lower compared to the milk intakes of 752 (18) $\mathrm{ml} /$ day for the Gambia infants and 670 (46) $\mathrm{ml} /$ day for the Papua New Guinea infants.
Table 3. Breast milk intake in infants and water turnover rates and body content of their mothers for the Pokot, Kenya, the Gambia and Papua New Guinea
Table 4. Effect of third trimester of pregnancy mid upper arm circumference on volume of breast milk intake in 10 exclusively breast-fed Pokot infants aged 2-4 months

\begin{tabular}{|c|c|c|c|}
\hline & Pokot study & Gambia study* & $\begin{array}{l}\text { Papua New } \\
\text { Guinea study* }\end{array}$ \\
\hline Number of children & 10 & 4 & 17 \\
\hline Age range, months & $2-4$ & $0-4$ & $0-4$ \\
\hline Total body water, $\%$ & $48.5 \pm 4.1$ & $59.7 \pm 2.7$ & $50.9 \pm 1.9$ \\
\hline Maternal water turnover, liters/day & $4.77 \pm 0.95$ & $5.93 \pm 0.25$ & $3.65 \pm 0.19$ \\
\hline \multicolumn{4}{|l|}{ Breast milk intake } \\
\hline $\mathrm{ml} /$ day & $552 \pm 22$ & $752 \pm 18$ & $670 \pm 46$ \\
\hline $\mathrm{ml} / \mathrm{kg}$ & $115 \pm 5$ & $152 \pm 9$ & $140 \pm 7$ \\
\hline
\end{tabular}

* Values reported by Coward et al. [5].

Values are mean \pm SE.

\begin{tabular}{lrrrrrr}
\hline & Coefficient (b) & SE & $\beta$ & p value & R & Adjusted, $R^{2}$ \\
\hline Infant milk intake & & & & & 0.725 & 0.467 \\
Constant & $-2,599.711$ & 1,059 & & 0.040 & & \\
MUAC* & 138.860 & 46 & 0.725 & 0.018 & & \\
\hline
\end{tabular}

* Third trimester mid upper arm circumference. 
Table 5. Nutritional status and estimated average daily breast milk volume and energy intake of the Pokot infants

\begin{tabular}{|c|c|}
\hline Males & 6 \\
\hline Females & 4 \\
\hline Birth weight, kg & $2.94 \pm 0.323$ \\
\hline Age at evaluation, months & $3.690 \pm 1.26$ \\
\hline Weight at evaluation, kg & $4.956 \pm 0.874$ \\
\hline Weight gain, g/day & $20 \pm 4$ \\
\hline Weight/age & $-1.750 \pm 0.77^{*}$ \\
\hline Volume of milk intake, $\mathrm{ml} /$ day & $552 \pm 22$ \\
\hline Energy from milk intake, $\mathrm{kJ} / \mathrm{day}^{\mathrm{a}}$ & $1,602 \pm 148$ \\
\hline Energy from milk intake, $\mathrm{kJ} / \mathrm{kg} / \mathrm{day}^{\mathrm{a}}$ & $333 \pm 154$ \\
\hline Infant energy requirement, $\mathrm{kJ} / \mathrm{day}^{\mathrm{b}}$ & $2,404 \pm 423$ \\
\hline \multicolumn{2}{|c|}{$\begin{array}{l}\text { Values are mean } \pm \mathrm{SD} \text {. } \\
* \mathrm{Z} \text { score from National Center for Health Statistics (NCHS). } \\
\text { a Based on an energy content of breast milk of } 2.9 \mathrm{~kJ} / \mathrm{g} \\
67 \mathrm{kcal} / \mathrm{g} \text { ). }\end{array}$} \\
\hline
\end{tabular}

The multiple regression models explained $47 \%$ of the variation in infant milk intake (table 4) Pokot women pregnancy MUAC was a positive predictor of the pastoral infant's breast milk intake. The infant milk intake was significantly and positively correlated to maternal pregnancy triceps $(\mathrm{r}=0.679, \mathrm{p}<0.05)$ and pregnancy MUAC $(\mathrm{r}=0.725, \mathrm{p}<0.05)$.

Table 5 shows nutritional status and estimated average daily breast milk volume and energy intake of the Pokot infant. The mean (SD) new born weight taken within 7 days of birth was $2.94 \pm 0.323 \mathrm{~kg}$. At $2-4$ months after birth the mean (SD) Z score of -1.750 (0.077) weight/age is below the 50th percentile (National Centre for Health Statistics). The mean (SD) weight gain of 20 (40) g/day corresponds to a mean (SD) milk intake of $552 \pm 22 \mathrm{ml} /$ day. This may not be sufficient to provide for normal growth during the first 2- to 4-month period after birth. The mean (SD) energy intake of $1,602 \mathrm{~kJ} /$ day is significantly lower $(\mathrm{p}<0.01)$ compared to the $\mathrm{FAO} / \mathrm{WHO} /$ UNU estimated 2,404 (423) kJ/day energy requirement of this age group. Only 20\% (2) of the infants met their energy requirements. The energy supplied by milk is $66 \%$ lower than the recommended intake.

\section{Discussion}

The deuterium dilution technique is proving to be useful for field studies examining body composition $[4,20]$ and infant breast milk intake [5-8]. The evaluation of breast milk intake is of particular importance for setting future breast-feeding recommendations and to investigate the effect of diet and environmental factors on maternal capacity for adequate lactation. The evaluation of body composition during field studies in developing countries is of particular importance for identifying intervention strategies aimed at improving nutrient intake. Establishing the volume of breast milk intake is of particular relevance to the estimation of adequacy of nutrient intake of the exclusively breast-fed infant [10].

The advantages of the deuterium dilution technique [4] are the noninvasive character of the measurements, the relative ease with which it can be applied to both the mothers and infants, and the possibility of combining this type of evaluation with other nutritional indices providing valuable information for nutritional interventions. To our knowledge this is one of the very few milk intake studies carried out in 2- to 4-month-old infants in Africa and the first in a pastoral community in Kenya. Previous Kenyan breast milk intake studies were carried out in farming communities and used the test weighing technique [21]. Studies conducted in lactating mothers in the Gambia and Papua New Guinea did not take maternal body composition into account [5].

A variety of information becomes available when DO is given to the mother. Maternal water turnover rate in the Pokot mothers is lower than that found in Papua New Guinea. This may be due to the effect of different levels of activity and different environmental conditions that promote water losses [5]. Comparisons between Pokot and Gambia mothers show that in the Gambia infant's water consumption was also derived from sources other than breast milk. The opposite happens for the Pokot lactating mother. Breast-feeding is almost completely exclusive and the infant derives little water from sources other than breast milk.

Among the Otomi Indians of Mexico, lactation performance was reported to be significantly correlated with maternal body size and composition [22]. Physically, the Otomi and Pokot mothers have a similar mean height of $1.47 \mathrm{~m}$ and a body weight of $50.5 \mathrm{~kg}$. The Otomi mothers BMI of 23.4 is higher. The Pokot mothers mean (SD) of 18.6 (1.3) is indicative of a low energy intake [23]. Expressed as a percentage of body weight the estimates of $\mathrm{BF}$ were higher at $23.6(6.4) \%$ and more comparable to $26.2(8.1) \%$ observed in Nandi lactating mothers. The mean (SD) $\mathrm{Hb}$ of 11.5 (1.3) g/dl during lactation is below the WHO cut-off point of $12 \mathrm{~g} / \mathrm{dl}$ [24]. When simple correlation tests were used, maternal pregnancy $\mathrm{Hb}$ levels were significantly correlated to the pregnancy Hct ratio. 
This suggests that iron status was likely to be an important determinant of $\mathrm{Hb}$ and hence anemia. Serum retinol levels were marginal and may indicate a risk of low dietary intake of vitamin A [25].

The method recommended by Coward et al. [5] was used to calculate infant milk-water intake. In this study, it is clear that on average, milk intake for this group of infants may be insufficient to provide the necessary energy for normal growth during the first 2-4 months of life $[1,2,26]$. This fact is relevant for many developing countries where stress is put on promotion of exclusive breastfeeding for the first 6 months of life [3]. The intake of the infants is $66 \%$ lower than the $485 \mathrm{~kJ} / \mathrm{kg} /$ day $\mathrm{FAO} / \mathrm{WHO} /$ UNU recommendation [1]. The infants' energy intake and pattern of growth based on weight/age is not comparable with those recommended for this age group. If this low level of energy intake is continuous then adequate growth may not be sustained.

Kenya like its neighbors in sub-Saharan Africa has the majority of their populations living in resource-poor communities, where child malnutrition remains a major health problem. This occurs as a result of poor child-feeding practices and exposure to high rates of infection. In this context, issues concerning measurement of both nutritional status and various environment exposures become increasingly significant. Like their better-nourished counterparts, women living under poor circumstances lose weight during lactation. The weight loss is magnified by seasonal changes in their environment. The amount of weight gained during pregnancy is higher with better living circumstances. The amount of weight retained after delivery shows this same discrepancy between poor and rich countries. The same trend may be observed when comparisons of body composition and micronutrient status are made either between the Nandi and Pokot lactating mothers (table 2) or between the Pokot mothers pregnancy and lactation periods (table 1).

The better-nourished Nandi lactating woman lives in an environment with better access to food and health care. In West Pokot, the lactating woman lives in a harsh environment. Undernutrition in this community is a function of declining food availability that is exacerbated by chronic food insecurity and limited access to health care. One season of poor rains, conflict and other hazards is sufficient to precipitate a crisis that results in poor harvests. A particularly relevant recent study [27] from Bangladesh goes even further. It accounts for initial maternal weight, duration of breast-feeding, and season in examining the effect of breast-feeding on maternal weight change. Weight loss was higher in lactating than in non-lactating women and lower in women with low initial weight than in those with high initial weight.

In most sub-Saharan community's season and time postpartum interacted so that women who reach the time of most intensive breast-feeding at a time of low food supply lose the most weight. For such communities, indirect markers of nutritional status such as body composition may provide direction for public health and nutrition policy at a national and multi-sectoral level. However, there is need for caution in the broad application of such indices. Ettyang et al. [9] have demonstrated that anthropometric measures of body composition in lactating women from a rural African community, using conventional equations, may overestimate body fatness and yield an unacceptable level of inaccuracy and be imprecise, when compared with DO method in the same group. Variability in the estimation of body composition in this study was related to the commonly used skinfold derived equations, originally formulated for populations in which food supply was plentiful, and for whom undernutrition was not a major public health issue. Formulation of timely and appropriate interventions requires accurate and rapid field assessment of the nutritional status of vulnerable groups. Attributes such as ease of administration, accuracy and validity of various measures of nutritional status create a platform supporting on going surveillance by the health sector.

New information on total daily energy expenditure and body composition of healthy children is based on longitudinal observations carried out in the developed countries. Subsequent estimations of nutrient requirements from complementary foods have assumed good maternal nutritional status and adequate breast milk volume and composition. It is recommended that nutrient requirements from complementary foods be estimated as the difference between young children's estimated total nutrient needs and the amounts transferred in breast milk to children of different ages [28]. In resource-poor communities, estimated total nutrient needs cannot be achieved unless priority is given to the identification and application of appropriate instruments that can be used to assess current infant feeding practices and monitor the impact of those nutrition interventions that aim at promoting exclusive infant breast-feeding. So far due to lack of simple tools to measure the adequacy of exclusive breast-feeding, imperfect proxy measures are widely used. As of now, indicators designed to determine whether the baby is exclusively breast-fed and not given water or other prelacteal feeds need to be developed. 
As shown in this study collecting information on volume of breast milk intake makes it possible to determine whether nutrient intake from breast milk would allow children of different ages to meet their energy and micronutrient requirements. The use of isotope provides assessment over a period of up to 14 days. In most breastfeeding studies the methods used tend to be based on a maternal recall period of $24 \mathrm{~h}$. This is because in order to maintain breast milk mothers have to breast-feed regularly. Thus, if they have not breast-fed the child in the previous $24 \mathrm{~h}$ it is unlikely that the child is receiving a meaningful amount of nutrients from breast milk. The major drawback of the recall method is when breast-feeding mothers are unable to remember the number of times they breast-fed their child during the previous day and night. There may therefore be a tendency for mothers to report having breast-fed as often as the child wants, implying that they breast-feed on demand. This may be highly desirable but it makes it very difficult to quantify the actual amount of breast milk consumed by the infant. Ability to determine the volume of breast milk consumed by the breast-fed infant is critical in estimating the amount of energy and nutrients that should be contributed by complementary foods.

In the past direct measures of breast milk intake have been complex, resulting in the use of small samples. With the technological advancements, such as the application of Fourier-transformed infrared spectrophotometry (FTIS) [8] for the analysis of DO isotope enrichment of urine samples, the application of stable isotope methodology will be more widely available. This may be an important step in preventing the misclassification or misinterpretation of nutritional status. In the future, larger samples can be used thus making it possible to review information on breast-feeding frequency as a basis of as- sessing whether breast milk intake is likely to be low, average or high. This technique can also be used to determine whether or not the information on breast-feeding frequency that is currently being collected in many studies around the world (in all nationally representative Demographic Household Surveys, for example) is useful in accurately differentiating between children who have low vs. high breast milk intake.

In both the Pokot and Nandi cultures breast-feeding is the norm. For the infant to get the full benefits of breastfeeding, lactating women must initiate and continue breast-feeding. Supporting women to continue breastfeeding in a relatively hostile environment is necessary. For this to occur, especially in the Pokot community, the biological, political and sociocultural environments must interact in a way that is supportive of breast-feeding. Determining maternal body composition and infant breast milk intake combined with other nutritional parameters is critical if we aim to prevent deficiencies that may cause impaired health and well-being later in life. The biochemical findings among the Pokot mothers indicate dietary inadequacies that require nutritional improvement. The volume of breast milk produced suggests that for this group of infants, the current levels of breast milk that they consume may not achieve adequate growth.

\section{Acknowledgements}

This study was supported by the MUNDO MOI University and Maastricht University project. I am grateful for the facilitation role played by the dean Prof. B.O. Khwa-Otsyula and the former dean of the Faculty of Health Sciences, Prof. H.N.K. arap Mengech. Special thanks go to the Chief, the village committees and the mothers of Nandi and West Pokot communities.

\section{References}

$1 \mathrm{FAO} / \mathrm{WHO} / \mathrm{UNU}$ : Energy and protein requirements: Report of the joint FAO/WHO Ad Hoc RI Expert Committee. WHO Technical Report Series 724. Geneva, WHO, 1985.

- 2 Lucas A, Ewing G, Roberts SB, Coward WA: How much energy does the breast fed infant consume and expend. BMJ 1987;295:75-78.

3 ACC/SCN: 4th Report - The World Nutrition Situation: Nutrition throughout the Life Cycle. Chapter 3: Breast-Feeding And Complementary Feeding 2000 (IFPRI - ACC/SCN).
4 Westerterp KR, Wouters L, van Marken Lichtenbelt WD: The Maastricht protocol for the measurement of body composition and energy expenditure with labeled water. Obes Res 1995;(suppl)3:49-57.

5 Coward WA, Cole TJ, Sawyer MB, Prentice AM: Breast-milk intake measurement in mixed-fed infants by administration of deuterium oxide to their mothers. Hum Nutr Clin Nutr. 1982;36:141-148.

6 Fjeld CR, Brown KH, Schoeller DA: Validation of the deuterium oxide method for measuring average daily milk intake in infants. Am J Clin Nutr 1988;48:671-679.
7 Butte NF, Villalpando S, Wong WW, FloresHuerta S: Human milk intake and growth faltering of rural Mesoamerindian infants. Am J Clin Nutr 1992;55:1109-1116.

- 8 Caire G, Calderon de la Barca AM, Bolanos $\mathrm{AV}$ : Measurement of deuterium oxide by infrared spectroscopy and isotope ratio mass spectrometry for quantifying daily milk intake of breast fed infants and maternal body fat. Food Nut Bull 2002;23:38-41. 
9 Ettyang GA, van Marken Lichtenbelt WD, Saris WHM, Westerterp KR: Assessment of body composition in lactating mothers in a rural African community using deuterium oxide dilution. South Afr J Clin Nutr 2004;17:10-15.

10 Butte NF: Nutrient Adequacy of Exclusive Breast-Feeding for the Term Infant During the First Six Months of Life. Geneva, World Health Organization, 2002.

11 Central Bureau of Statistics: The first report of poverty in Kenya: Incidence and Depth of Poverty. Nairobi, Ministry of Planning \& National Development (CBS), 1998, vol 1.

-12 Infante C, Hurtado J, Salazar G, Pollastri A, Aguirre E, Vio F: The dose-to-mother method to measure milk intake in infants by deuterium dilution: Validation study. Eur J Clin Nutr 1991;45:121-129.

13 Westerterp KR: Body composition, water turnover and energy turnover assessment with labelled water. Proc Nutr Soc 1999;58:945951.

14 Gibson RS: Anthropometric measurement of body composition; in Gibson RS (ed): Principles of Nutritional Assessment. New York, Oxford University Press, 1990, pp 187-208.
5 Cook JD, Finch CA: Assessing iron status of a population. Am J Clin Nutr 1979;32:21152119.

-16 ScrimgeourCM, Rollo MM, MudamboSMKT, Handley LL Prosser SJ: A simplified method for deuterium/hydrogen isotope ratio measurements on water samples of biological origin. Biol Mass Spectrometry 1993;22;383-387.

17 Wong WW, Lee LS, Klein PD: Deuterium and ${ }^{18}$ oxygen measurements on microlitre samples of urine, plasma, saliva and human milk. Am J Clin Nutr 1987;45:905-913.

18 Raaij JMA, van Peek MEM, Vermaart-Miedema SH, Schonk CM, Hautvast JGAJ: New equations for estimating body fat mass in pregnancy from body density or total body water. Am J Clin Nutr 1988;48:24-29.

19 Sehmi JK: National Food Composition Tables and the Planning of Satisfactory Diets 1993. Nairobi, Government of Kenya Press, 1993.

20 Van Marken Lichtenbelt WD, Westerterp KR, Wouters L: Deuterium dilution as a method for determining total body water: effect of test protocol and sampling time. Br J Nutr 1994;72: 491-497.

21 Jansen AA, Horelli H T, Quinn VJ: Food and Nutrition in Kenya. A Historical Review. Nairobi, Government of Kenya Press, 1987.
22 Villalpando SF, Butte NF, Wong WW, FloresHuerta S, Hernandez-Beltran MJ, Smith EO, Garza C: Lactation performance of rural Mesoamerindians. Eur J Clin Nutr 1992;46:337348.

23 Shetty PS: Adaptation to low energy intakes: The responses and limits to low intakes in infants, children, and adults. Eur J Clin Nutr 1999;53(suppl 1):S14-33.

24 WHO: The Prevalence of Anaemia in Women: A Tabulation of Available Information, ed 2. Geneva, World Health Organization, 1992.

25 Underwood BA: Maternal vitamin A status and its importance in infancy and early childhood. Am J Clin Nutr 1994;59(suppl):517S$524 \mathrm{~S}$.

26 Salazar G, Vio F, Garcia C, Aguirre E, Coward WA: Energy requirements in Chilean infants. Arch Dis Child 2000;83:F120-123.

27 Rodriguez G, Pebley AR: Lactation, seasonality and mother's postpartum weight change in Bangladesh: An analysis of maternal depletion. Am J Hum Biol 1994;6:511-524.

28 Brown K, Dewey K, Allen L: Complementary Feeding of Young Children in Developing Countries: A Review of Current Scientific Knowledge. Geneva, WHO, 1998. 